\title{
Gambaran Kejadian Pneumonia pada Pasien Pasca Kraniotomi di Ruang Rawat Intensif RSUD Arifin Achmad Provinsi Riau Periode Januari 2015 sampai Desember 2019
}

\author{
Andrea Valentino $^{1 *}$, Rita Endriani ${ }^{2}$, Fitria Ameini ${ }^{3}$
}

\begin{abstract}
Craniotomy is the procedure to open part of the skull plate to provide direct access to the brain. The most common complications is ventilator-associated pneumonia (VAP) and healthcare-associated pneumonia (HAP). This study was conducted to see an overview of the incidence of pneumonia in post-craniotomy patients in the ICU at Arifin Achmad General Hospital, Riau Province for the period January 2015 to December 2019. The source of data were from the medical record of post-craniotomy patients, with total 216 medical records. Result showed that, the incidence of pneumonia was found in 56 patients $(25.9 \%)$, with the incidence of HAP $3.7 \%$ and VAP $22.7 \%$. The incidence of HAP was more common in female (62.5\%) with the age group of 56-65 years old (50\%), and the length of stay $>5$ days $(75 \%)$. The incidence of VAP has the same distribution between male and female $(50 \%)$ with the age group 36-45 years old $(29.2 \%)$, the length of stay $>5$ days $(45.8 \%)$, and the length of using mechanical ventilator $<96$ hours $(66.7 \%)$. The incidence of pneumonia mostly occurred in patients without comorbid $(71.4 \%)$ or had a hypertension as comorbid (21.4\%) with a diagnosis of meningioma (28.6\%), leukocytes count $>11.000(76.8 \%)$, duration of surgery $\geq 2$ hours (55.4\%), and the most common pathogens were Acinetobacter baumannii (30.3\%). The mortality rate found in this study was $7.1 \%$.
\end{abstract}

Keywords: craniotomy, pneumonia, VAP, HAP

Kraniotomi merupakan tindakan membuka sebagian tulang tengkorak hingga dapat memberikan akses langsung menuju otak yang dilakukan oleh dokter spesialis bedah saraf. ${ }^{1}$ Operasi kraniotomi dapat dibagi berdasarkan sifat pembedahannya yaitu yang dilakukan secara cito dan secara elektif. ${ }^{2}$ Tindakan ini dilakukan atas beberapa indikasi seperti kasus trauma maupun non trauma. ${ }^{3}$

$$
\text { Menurut penelitian di Manado, }
$$

Penulis korespondensi:dr_reano@yahoo.com

${ }^{1} \mathrm{KJF} / \mathrm{KSM}$ Bedah Fakultas Kedokteran Universitas

Riau/ RSUD Arifin Achmad Provinsi Riau,

Pekanbaru, Riau, Indonesia

${ }^{2}$ KJF Mikrobiologi Fakultas Kedokteran Universitas

Riau, Pekanbaru, Riau, Indonesia

${ }^{3}$ Fakultas Kedokteran Universitas Riau, Pekanbaru,

Riau, Indonesia ditemukan 30 kasus operasi kraniotomi dengan diagnosis terbanyak berupa cedera kepala sebesar $77 \%$ pada jenis kelamin lakilaki sebesar $90 \% .{ }^{4}$ Penelitian di Surakarta menemukan dalam 58 kasus operasi kraniotomi, 38 pasien $(66 \%)$ harus menggunakan ventilator mekanik pasca kraniotomi dan dirawat di ruang Intensive Care Unit (ICU). ${ }^{5}$ Penggunaan ventilator mekanik diperlukan karena pasien pasca kraniotomi memiliki potensi mengalami penurunan jalan napas sehingga membutuhkan alat bantu untuk menjaga pernapasannya. ${ }^{6,7}$

Pemakaian ventilator mekanik dan perawatan yang cukup lama di ruang ICU dapat menimbulkan berbagai komplikasi. Salah satu komplikasi yang sering terjadi adalah pneumonia, dalam hal ini termasuk ke dalam pneumonia nosokomial. Pneumonia 
merupakan peradangan yang mengenai parenkim paru, distal dari bronkiolus terminalis yang mencakup bronkiolus respiratorius dan alveoli, serta menimbulkan konsolidasi jaringan paru dan gangguan pertukaran gas setempat. ${ }^{8}$ Pneumonia nosokomial merupakan pneumonia yang terjadi di dalam lingkungan rumah sakit (RS), terdiri dari healthcare associated pneumonia (HAP) dan ventilator associated pneumonia (VAP). ${ }^{9}$

Healthcare associated pneumonia merupakan pneumonia yang terjadi pada pasien yang dirawat di RS $>48$ jam, baik di ruang umum maupun ruang ICU tanpa menggunakan ventilator mekanik. Ventilator associated pneumonia merupakan pneumonia yang terjadi setelah pemakaian ventilasi mekanik $>48-72$ jam. Ventilator mekanik merupakan alat yang digunakan untuk membantu pasien dalam bernapas, dapat berupa endotracheal tube (ETT) maupun trakeostomi. ${ }^{8}$ Penelitian di Jambi menemukan kasus pneumonia di ruang ICU pada 22 pasien yang terdiri dari VAP 9 pasien $(40,9 \%)$, HAP 8 pasien $(36,4 \%) .{ }^{10}$ Menurut penelitian yang dilakukan di RS Cipto Mangunkusumo dengan total sampel 201 pasien yang mengalami VAP dan dirawat di ruangan ICU, 115 (57,2\%) diantaranya mengalami kematian ${ }^{11}$ dan penelitian yang dilakukan diwaktu yang berbeda ditemukan dari total 204 pasien yang terdiagnosis HAP, sebanyak 90 orang pasien $(44,1 \%)$ diantaranya mengalami kematian. ${ }^{12}$

Patogen penyebab pneumonia dapat bervariasi dan dapat berupa infeksi monobakterial maupun multibakterial. ${ }^{13}$ Berdasarkan hasil dari beberapa penelitian dapat dilihat beberapa patogen yang paling sering menyebabkan pneumonia di ruang ICU seperti penelitian di Korea Selatan Staphylococcus aureus $(45,7 \%)^{14}$, dan India Acinobacter spp. $(44,4 \%)^{15}$. Data yang didapatkan dari hasil penelitian yang dilakukan di Indonesia juga tidak jauh berbeda. Patogen yang paling sering menyebabkan pneumonia di ruang ICU merupakan Acinetobacter spp. $(38,7 \%)$ diikuti Klebsiella pneumoniae (25\%). ${ }^{11}$

\section{METODE}

Penelitian ini merupakan penelitian deskriptif retrospektif yang dilaksanakan dari bulan Februari s/d Agustus 2020 di Instalasi Rekam Medik RSUD Arifin Achmad Provinsi Riau. Populasi penelitian ini merupakan seluruh data rekam medik pasien yang menjalani operasi kraniotomi di RSUD Arifin Achmad Provinsi Riau periode Januari 2015 s/d Desember 2019. Sampel penelitian ini diambil dengan cara total sampling, yang memenuhi kriteria inklusi yaitu, seluruh data rekam medik pasien yang menjalani operasi kraniotomi dan dirawat di ruang rawat intensif RSUD Arifin Achmad Provinsi Riau dalam periode Januari 2015 s/d Desember 2019 dan memiliki data yang lengkap, dan kriteria eksklusi berupa data rekam medik pasien yang telah mengalami infeksi pneumonia sebelum menjalani operasi kraniotomi dan data rekam medik pasien yang tidak lengkap. Pengolahan data penelitian ini dilakukan secara komputerisasi dengan program SPSS dan disajikan dalam tabel distribusi dan narasi. Penelitian telah mendapatkan persetujuan etik dari Unit Etik Penelitian Kedokteran dan Kesehatan Fakultas Kedokteran Universitas Riau dengan nomor : B/050/UN 19.5.1.1.8/UEPKK/2020.

\section{HASIL}

\section{Angka Kejadian Pneumonia}

Penelitian ini dilakukan pada bulan Februari s/d Agustus 2020 di Bagian Rekam Mediks RSUD Arifin Achmad Provinsi Riau. Berdasarkan penelitian ini didapatkan sampel sebanyak 269 pasien dan banyak sampel yang memenuhi kriteria inklusi serta eksklusi adalah 216 pasien dengan gambaran angka kejadian pneumonia sebanyak 56 orang $(26 \%)$. Angka kejadian HAP adalah sebanyak 8 orang 
(3,7\%). Distribusi pasien yang menggunakan bantuan ventilator mekanik sebanyak 211 orang $(97,7 \%)$, dan didapatkan sebanyak 48 orang yang mengalami VAP (22,7\%).

\section{Distribusi Kejadian HAP dan VAP berdasarkan Karakteristik Pasien}

Distribusi kejadian HAP dan VAP yang tejadi berdasarkan karateristik pasien dapat dilihat pada Tabel 1 berikut.

Tabel 1. Distribusi kejadian HAP dan VAP berdasarkan karakteristik pasien

\begin{tabular}{|c|c|c|}
\hline Jenis Kelamin & Frekuensi $(\mathrm{N})$ & Persentase (\%) \\
\hline \multicolumn{3}{|l|}{ HAP } \\
\hline Laki laki & 3 & 37,5 \\
\hline Perempuan & 5 & 62,5 \\
\hline Total & 8 & 100 \\
\hline \multicolumn{3}{|l|}{ VAP } \\
\hline Laki laki & 24 & 50 \\
\hline Perempuan & 24 & 50 \\
\hline Total & 48 & 100 \\
\hline $\begin{array}{l}\text { Kelompok Usia } \\
\text { HAP }\end{array}$ & Frekuensi (N) & Persentase (\%) \\
\hline 17-25 tahun & 1 & 12,5 \\
\hline 26-35 tahun & 1 & 12,5 \\
\hline 36-45 tahun & 0 & 0 \\
\hline 46-55 tahun & 2 & 25 \\
\hline 56-65 tahun & 4 & 50 \\
\hline Total & 8 & 100 \\
\hline \multicolumn{3}{|l|}{ VAP } \\
\hline 17-25 tahun & 7 & 14,6 \\
\hline 26-35 tahun & 5 & 10,4 \\
\hline $36-45$ tahun & 14 & 29,2 \\
\hline 46-55 tahun & 10 & 20,8 \\
\hline 56-65 tahun & 7 & 14,6 \\
\hline$>65$ tahun & 5 & 10,4 \\
\hline Total & 48 & 100 \\
\hline Jenis Komorbid & Frekuensi $(\mathrm{N})$ & Persentase (\%) \\
\hline Tidak ada & 40 & 71,4 \\
\hline Hipertensi & 12 & 21,4 \\
\hline Diabetes & 2 & 3,6 \\
\hline Melitus & & \\
\hline \multicolumn{3}{|l|}{ Hipertensi } \\
\hline PPOK & 1 & 1,8 \\
\hline Diabetes & 1 & 1,8 \\
\hline \multicolumn{3}{|l|}{ Melitus } \\
\hline Total & 56 & 100 \\
\hline
\end{tabular}

Berdasarkan Tabel 1, kejadian HAP lebih banyak ditemukan pada pasien perempuan yaitu 5 orang $(62,5 \%)$, sedangkan pada kejadian VAP ditemukan kejadian pada laki-laki dan perempuan dengan jumlah yang sama yaitu sebanyak 24 orang (50\%). Berdasarkan Tabel 1, distribusi kejadian HAP lebih banyak ditemukan pada kelompok usia 56-65 tahun yaitu 4 orang (50\%), sedangkan kejadian VAP lebih banyak ditemukan pada kelompok usia 36-45 tahun yaitu 14 orang (29,2\%). Gambaran kejadian pneumonia berdasarkan komorbid ditemukan sebanyak 40 pasien $(71,4 \%)$ tidak memiliki komorbid dan sisanya sebanyak 16 orang $(28,6 \%)$ memiliki komorbid. Jenis yang paling sering terjadi yaitu hipertensi sebanyak 12 orang $(21,4 \%)$.

\section{Gambaran Kejadian Pneumonia berdasarkan Klinis Pasien}

Berdasarkan Tabel 2, kejadian pneumonia lebih banyak terjadi pada pasien dengan diagnosis pre operasi non trauma sebanyak 40 orang $(71,4 \%)$, diagnosis pra operasi yang paling banyak terjadi merupakan meningioma sebanyak 16 orang $(28,6 \%)$. Jumlah leukosit terbanyak pada kelompok > 11000 sebanyak 43 orang $(76,8 \%)$, sifat pembedahan cito dan elektif memiliki frekuensi yang sama yaitu 28 orang $(50 \%)$, pasien yang paling banyak mengalami kejadian pneumonia merupakan pada kelompok lama pembedahan sama atau lebih dari 2 jam yaitu sebanyak 31 orang $(55,4 \%)$.

\section{Gambaran Kejadian HAP dan VAP berdasarkan Lama Rawatan di Ruang ICU}

Gambaran kejadian VAP dan HAP berdasarkan lama rawatan pasien di ruang ICU dapat dilihat pada Tabel 3. Berdasarkan Tabel 3 kejadian HAP dan VAP paling banyak terjadi pada kelompok lama rawatan lebih dari 5 hari yaitu 22 orang $(45,8 \%)$ dan 6 orang $(75 \%)$.

\section{Gambaran Kejadian VAP berdasarkan Lama Pemakaian Ventilator Mekanik}

Gambaran kejadian VAP berdasarkan lamanya pemakaian ventilator mekanik dapat dilihat pada Tabel 4. Berdasarkan Tabel 4 dapat dilihat onset terjadinya VAP lebih banyak terjadi pada onset dini yaitu 32 orang $(66,7 \%)$. 
Tabel 2. Gambaran kejadian pneumonia berdasarkan klinis pasien

\begin{tabular}{|c|c|c|c|}
\hline \multicolumn{2}{|c|}{$\begin{array}{c}\text { Jenis Diagnosis Pra- } \\
\text { operasi }\end{array}$} & $\begin{array}{l}\text { Frekuensi } \\
(\mathrm{N})\end{array}$ & $\begin{array}{l}\text { Persentase } \\
\quad(\%)\end{array}$ \\
\hline \multirow{8}{*}{ Trauma } & $\begin{array}{l}\text { Cedera kepala } \\
\text { sedang }\end{array}$ & & \\
\hline & SUDAH & 4 & 7,1 \\
\hline & $\mathrm{ICH}$ & 3 & 5,3 \\
\hline & $\begin{array}{l}\text { Cedera kepala } \\
\text { berat }\end{array}$ & & \\
\hline & $\mathrm{EDH}$ & 4 & 7,1 \\
\hline & SUDAH & 2 & 3,6 \\
\hline & $\mathrm{ICH}$ & 2 & 3,6 \\
\hline & $\begin{array}{l}\text { Depressed } \\
\text { temporal }\end{array}$ & 1 & 1,8 \\
\hline \multirow{10}{*}{$\begin{array}{l}\text { Non } \\
\text { trauma }\end{array}$} & Meningioma & 16 & 28,6 \\
\hline & Stroke & 11 & 19,6 \\
\hline & Hemoragik & & \\
\hline & $\begin{array}{l}\text { Glioblastoma } \\
\text { multiforme }\end{array}$ & 5 & 8,9 \\
\hline & Hidrosefalus & 2 & 3,6 \\
\hline & $\begin{array}{l}\text { Low grade } \\
\text { glioma }\end{array}$ & 2 & 3,6 \\
\hline & Abses cerebri & 1 & 1,8 \\
\hline & Ependymoma & 1 & 1,8 \\
\hline & Metastasis & 1 & 1,8 \\
\hline & Stroke infark & 1 & 1,8 \\
\hline & & 56 & 100 \\
\hline \multicolumn{2}{|c|}{ Kelompok jumlah leukosit } & $\begin{array}{l}\text { Frekuensi } \\
(\mathrm{N})\end{array}$ & $\begin{array}{c}\text { Persentase } \\
(\%)\end{array}$ \\
\hline & 2 & 3,6 \\
\hline \multicolumn{2}{|c|}{$6000-11000$} & 11 & 19,6 \\
\hline & 43 & 76,8 \\
\hline \multicolumn{2}{|l|}{ Total } & 56 & 100 \\
\hline \multicolumn{2}{|c|}{ Sifat pembedahan } & $\begin{array}{c}\text { Frekuensi } \\
(\mathrm{N})\end{array}$ & $\begin{array}{c}\text { Persentase } \\
(\%)\end{array}$ \\
\hline \multicolumn{2}{|l|}{ Cito } & 28 & 50 \\
\hline \multicolumn{2}{|l|}{ Elektif } & 28 & 50 \\
\hline \multicolumn{2}{|l|}{ Total } & 56 & 100 \\
\hline \multicolumn{2}{|c|}{ Lama pembedahan } & $\begin{array}{l}\text { Frekuensi } \\
(\mathrm{N})\end{array}$ & $\begin{array}{c}\text { Persentase } \\
(\%)\end{array}$ \\
\hline \multicolumn{2}{|l|}{$<2$ Jam } & 25 & 44,6 \\
\hline \multicolumn{2}{|l|}{$\geq 2$ Jam } & 31 & 55,4 \\
\hline \multicolumn{2}{|l|}{ Total } & 56 & 100 \\
\hline
\end{tabular}

\section{Distribusi Kejadian Pneumonia berdasarkan Patogen Penyebab}

Gambaran kejadian pneumonia berdasarkan jenis patogen penyebabnya dapat dilihat pada Tabel 5. Berdasarkan Tabel 5, patogen penyebab pneumonia pada pasien pasca kraniotomi di ruang ICU RSUD Arifin Achmad Provinsi Riau periode Januari 2015 s/d Desember 2019 paling banyak merupakan
Tabel 3. Gambaran kejadian VAP dan HAP berdasarkan lama rawatan

\begin{tabular}{|c|c|c|}
\hline Lama Rawatan & Frekuensi $(\mathrm{N})$ & Persentase (\%) \\
\hline \multicolumn{3}{|l|}{ HAP } \\
\hline 2-3 hari & 1 & 12,5 \\
\hline 4-5 hari & 1 & 12,5 \\
\hline$>5$ hari & 6 & 75 \\
\hline Total & 8 & 100 \\
\hline \multicolumn{3}{|l|}{ VAP } \\
\hline$<2$ hari & 5 & 10,4 \\
\hline 2-3 hari & 9 & 18,8 \\
\hline 4-5 hari & 12 & 25 \\
\hline$>5$ hari & 22 & 45,8 \\
\hline Total & 48 & 100 \\
\hline
\end{tabular}

Tabel 4 Gambaran kejadian VAP berdasarkan lamanya pemakaian ventilator mekanik

\begin{tabular}{lcc}
\hline $\begin{array}{l}\text { Lama pemakaian } \\
\text { ventilator mekanik }\end{array}$ & $\begin{array}{c}\text { Frekuensi } \\
(\mathrm{N})\end{array}$ & Persentase (\%) \\
\hline <96 Jam & 32 & 66,7 \\
>96 Jam & 16 & 33,3 \\
\hline Total & 48 & 100 \\
\hline
\end{tabular}

Tabel 5. Gambaran kejadian pneumonia berdasarkan jenis patogen penyebab

\begin{tabular}{|c|c|c|}
\hline Petogen penyebab & $\begin{array}{l}\text { Frekuensi } \\
(\mathrm{N})\end{array}$ & $\begin{array}{c}\text { Persentase } \\
(\%)\end{array}$ \\
\hline $\begin{array}{l}\text { Acinetobacter } \\
\text { baumanii }\end{array}$ & 17 & 30,3 \\
\hline $\begin{array}{l}\text { Klebsiella } \\
\text { pneumoniae }\end{array}$ & 14 & 25 \\
\hline Pseudomonas sp. & 9 & 16,1 \\
\hline $\begin{array}{l}\text { Staphylococcus } \\
\text { aureus }\end{array}$ & 6 & 10,7 \\
\hline $\begin{array}{l}\text { Achromobacter } \\
\text { sp. }\end{array}$ & 2 & 3,6 \\
\hline $\begin{array}{l}\text { Stenotrophomonas } \\
\text { maltophilia }\end{array}$ & 2 & 3,6 \\
\hline $\begin{array}{l}\text { Burkholderia } \\
\text { cepacia }\end{array}$ & 1 & 1,8 \\
\hline Citobacter koseri & 1 & 1,8 \\
\hline E. coli & 1 & 1,8 \\
\hline $\begin{array}{l}\text { Enterobacter } \\
\text { cloacae }\end{array}$ & 1 & 1,8 \\
\hline Pantoea spp. & 1 & 1,8 \\
\hline $\begin{array}{l}\text { Serratia } \\
\text { marcescens }\end{array}$ & 1 & 1,8 \\
\hline Total & 56 & 100 \\
\hline
\end{tabular}

Tabel 6. Angka mortalitas kejadian pneumonia pasca kraniotomi

\begin{tabular}{|c|c|c|}
\hline Status keluar & Frekuensi (N) & $\begin{array}{c}\text { Persentase } \\
(\%)\end{array}$ \\
\hline Perbaikan kondisi & 49 & 87,5 \\
\hline $\begin{array}{l}\text { Pulang atas } \\
\text { permintaan sendiri }\end{array}$ & 3 & 5,4 \\
\hline Meninggal & 4 & 7,1 \\
\hline Total & 56 & 100 \\
\hline
\end{tabular}


Acinetobacter baumanii yaitu sebanyak 17 orang (30,3\%) diikuti Klebsiella pneumoniae 14 orang (25\%).

\section{Angka Kematian Kejadian Pneumonia pada Pasien Pasca Kraniotomi}

Angka kematian kejadian pneumonia pada pasien pasca kraniotomi dapat dilihat pada Tabel 6. Berdasarkan Tabel 6, dapat dilihat dari total 56 pasien yang mengalami pneumonia 4 orang diantaranya $(7,1 \%)$ meninggal dunia.

\section{PEMBAHASAN}

\section{Angka Kejadian Pneumonia}

Berdasarkan hasil penelitian, didapatkan kejadian pneumonia pada 56 rekam medik (26\%). Pada penelitian yang dilakukan di Beijing, Cina pada bulan Agustus 2012 s/d Februari 2013, ditemukannya sebanyak 20 pasien $(12,3 \%)$ dari total 162 pasien yang menjalani operasi kraniotomi mengalami komplikasi berupa pneumonia. ${ }^{16}$ Kejadian pneumonia pada pasien pasca kraniotomi dapat terjadi akibat beberapa faktor, seperti diakibatkan oleh kelemahan otot-otot pernapasan ataupun terdapatnya gangguan pada sistem saraf pusat dalam pengaturan refleks batuk dan menelan yang menyebabkan penumpukan sputum pada jalan napas yang selanjutnya akan memudahkan patogen penyebab infeksi untuk tumbuh. ${ }^{13,17}$

\section{Angka Kejadian HAP}

Pada penelitian ini, kejadian HAP ditemukan yaitu sebanyak 8 rekam medik $(3,7 \%)$ dari total 216 rekam medik pasien. Hasil ini lebih rendah dibandingkan penelitian yang dilakukan di Amerika yang mendapatkan kejadian HAP sebanyak 42 pasien $(30 \%){ }^{18}$ Kejadian HAP pada pasien pasca kraniotomi atau pada pasien pasca bedah saraf secara umum termasuk rentan untuk terjadi. Hal ini dikarenakan kebutuhan pasien-pasien tersebut untuk melakukan tirah baring yang lama, disfagia, perubahan kondisi mental, dan kelemahan otot pernapasan. ${ }^{13,14}$

\section{Angka Kejadian VAP}

Berdasarkan hasil penelitian ini, sebanyak 211 rekam medik $(97,7 \%)$ di antaranya merupakan pasien pasca kraniotomi yang membutuhkan bantuan ventilator mekanik di ruang ICU, dan 48 diantaranya (22,7\%) didiagnosis sebagai VAP. Penelitian di Surakarta menemukan sebanyak 38 pasien $(66 \%)$ dari total 58 kasus kraniotomi harus menggunakan ventilator mekanik. ${ }^{5}$ Menurut penelitian yang dilakukan oleh Irene dkk, ditemukan sebanyak 334 kasus kraniotomi dan 75 orang $(22,5 \%)$ diantaranya mengalami VAP. ${ }^{19}$ Penggunaan ventilator mekanik umumnya dilakukan pada pasien dengan Glasgow coma scale (GCS) $<8$ tidak dapat melindungi saluran napas mereka, sama halnya dengan pasien yang memiliki disfungsi pada saraf kranial berisiko cukup tinggi jika refleks laring, batuk, dan menelan berkurang. Kontrol pernapasan juga dapat terganggu akibat tindakan kraniotomi yang dilakukan. Hal ini pada akhirnya dapat mengakibatkan terjadinya periode apnea, sehingga bantuan ventilator mekanik sangat dibutuhkan. ${ }^{20}$ Penggunaan ventilator mekanik yang lama atau $>48$ jam inilah yang selanjutnya meningkatkan risiko terjadinya VAP.

\section{Distribusi Kejadian HAP dan VAP Berdasarkan Jenis Kelamin}

Berdasarkan hasil penelitian, kejadian HAP lebih banyak terjadi pada perempuan, yaitu sebanyak 5 orang $(62,5 \%)$. Hal tersebut berbeda dengan kejadian VAP yang memiliki distribusi kejadian yang sama antara perempuan dan laki-laki (50\%). Penelitian di RSCM menemukan kejadian HAP lebih banyak terjadi pada laki-laki, yaitu sebanyak 109 orang $(53,4 \%){ }^{12}$ Penelitian di RSCM di waktu yang berbeda menemukan distribusi kejadian VAP juga lebih banyak terjadi pada laki-laki yaitu sebanyak 108 pasien $(53,7 \%) .{ }^{11}$ Menurut literatur, mengatakan bahwa memang tidak ada hubungan yang signifikan 
antara kejadian HAP dan VAP dengan jenis kelamin. ${ }^{21}$

\section{Distribusi Kejadian HAP dan VAP Berdasarkan Usia}

Berdasarkan hasil penelitian ini, didapatkan pada kasus HAP lebih banyak terjadi pada kelompok usia 56-65 tahun sebanyak 4 orang $(50 \%)$. Pada penelitian yang dilakukan di RSCM menemukan kejadian HAP paling banyak terjadi pada kelompok usia $<60$ tahun yaitu sebanyak 139 orang $(68,2 \%) .{ }^{12}$ Berbeda dari kasus HAP, pada kasus VAP paling banyak terjadi pada kelompok usia 36-45 tahun sebanyak 14 orang $(29,2 \%)$. Penelitian yang dilakukan Dipendra dkk. menemukan kelompok usia 15-25 tahun lebih banyak mengalami kejadian VAP, yaitu sebesar $25,7 \% .^{22}$ Beberapa penelitian mengatakan bahwa kemungkinan angka kejadian HAP dan VAP akan meningkat lebih dari 1,15 kali lipat setiap peningkatan usia 1 tahun. Hal ini dapat disebabkan akibat penurunan fungsi fisiologis pernapasan, penurunan elastisitas jaringan paru secara bertahap, dan refleks batuk yang melemah. ${ }^{23,24}$

\section{Gambaran Kejadian Pneumonia Berdasarkan Komorbid}

Berdasarkan hasil penelitian, ditemukan sebanyak 40 orang $(71,4 \%)$ di antaranya tidak memiliki penyakit penyerta atau komorbid dan 16 orang lainnya $(28,6 \%)$ memiliki komorbid. Jenis komorbid yang paling banyak ditemukan merupakan hipertensi sebanyak 12 orang $(21,4 \%)$. Pada penelitian yang dilakukan di RSCM menemukan bahwa sebanyak 118 pasien $(58,7 \%)$ tidak memiliki komorbid, dan 83 pasien (41,3\%) lainnya memiliki komorbid berupa hipertensi (19,9\%), immunocompromise (19,4\%), dan diabetes melitus $(14,9 \%) .{ }^{11}$ Keadaan komorbid dapat mempengaruhi tingkat kekebalan tubuh pasien terhadap infeksi dari luar. Salah satu komorbid yang paling sering terjadi adalah hipertensi. Hipertensi berhubungan dengan aktivasi berlebihan pada sistem nervus simpatik dan menyebabkan keadaan imunodefisiensi. ${ }^{25}$

\section{Gambaran Kejadian Pneumonia Berdasarkan Diagnosis Pra-Operasi}

Berdasarkan penelitian ini, diagnosis pra operasi yang didapatkan dikelompokkan menjadi dua, yaitu kasus trauma dan non trauma. Kasus non trauma merupakan kelompok yang paling banyak ditemukan yaitu sebanyak 40 orang $(71,4 \%)$ dengan diagnosis berupa meningioma pada 16 orang (28,6\%) diikuti stroke hemoragik sebanyak 11 orang $(19,6 \%)$. Sedangkan kasus trauma ditemukan pada 16 orang $(28,6 \%)$ dengan diagnosis yang paling banyak berupa cedera kepala sedang (CKS) dengan perdarahan subdural (SDH) dan cedera kepala berat (CKB) dengan perdarahan epidural (EDH), yaitu sebanyak 4 orang $(7,1 \%)$. Penelitian yang dilakukan di Manado menemukan diagnosis pra-operasi paling banyak berupa cedera kepala dengan perdarahan epidural yaitu sebesar $40 \%$ diikuti cedera kepala dengan perdarahan subdural sebesar 33\%. ${ }^{4}$ Penyakit yang mempengaruhi sistem saraf pusat memiliki kemungkinan yang cukup besar untuk mengakibatkan hipoksia dan/atau hiperkapnea. ${ }^{26}$ Kasus non trauma seperti tumor akan sangat mempengaruhi pusat pernapasan, terutama jika lokasinya terdapat pada bagian medulla oblongata, namun mekanisme terjadinya belum jelas. Sedangkan diagnosis lainnya seperti pada stroke, dapat menyebabkan kelemahan pada diafragma sehingga juga mengganggu pernapasan. ${ }^{27}$

\section{Gambaran Kejadian Pneumonia Berdasarkan Jumlah Leukosit Pra Bedah}

Berdasarkan hasil penelitian ini, ditemukan kejadian pneumonia pada pasien pasca operasi kraniotomi paling banyak terjadi pada pasien yang memiliki jumlah leukosit pra bedah $>11.000$, yaitu pada 43 orang $(76,8 \%)$. Pada penelitian di Jambi didapatkan jumlah leukosit dalam rentang $5.120 \mathrm{~s} / \mathrm{d} 31.030$ dalam kejadian pneumonia pasca kraniotomi. ${ }^{10}$ Kadar leukosit merupakan salah satu faktor 
risiko yang dapat mencerminkan status infeksi dan perubahan sistem kekebalan tubuh. Pasien dengan jumlah leukosit $>11.000$ atau leukositosis memiliki insiden terjadinya komplikasi infeksi luka operasi dan komplikasi medik seperti pneumonia, infeksi saluran kemih, dll. yang lebih tinggi. ${ }^{28}$

\section{Gambaran Kejadian Pneumonia berdasarkan Sifat Pembedahan}

Berdasarkan hasil penelitian ini, sifat pembedahan yang dilakukan pada kejadian pneumonia pasca kraniotomi memiliki distribusi yang sama yaitu ditemukan masing-masing 28 orang (50\%) pada pembedahan bersifat cito maupun elektif. Pada penelitian yang dilakukan di Semarang, menemukan angka pembedahan yang bersifat elektif lebih tinggi (75\%) dibandingkan yang bersifat cito. ${ }^{28}$ Hal ini berbanding terbalik pada hasil yang didapatkan pada penelitian di Brazil yang mendapatkan pembedahan yang bersifat cito lebih banyak mengakibatkan kejadian pneumonia $(30,7 \%) .{ }^{29}$ Menurut literatur, pembedahan yang bersifat cito cenderung memiliki angka kejadian infeksi yang lebih tinggi dibandingkan pada pembedahan yang bersifat elektif. Hal ini dikarenakan pada pembedahan cito, komplikasi akan lebih mudah terjadi akibat kondisi pasien yang tidak optimal, karena pembedahan harus dilakukan secara segera. Namun, pada pembedahan elektif juga memiliki kemungkinan untuk menyebabkan komplikasi pasca operasi, diakibatkan karena lamanya pembedahan atau adanya penyulit ketika dilakukannya pembedahan, seperti terjadinya perdarahan. ${ }^{28}$

\section{Gambaran Kejadian Pneumonia Berdasarkan Lama Pembedahan}

Berdasarkan hasil penelitian ini, kejadian pneumonia paling banyak terjadi pada kelompok lama pembedahan $\geq 2$ jam, yaitu sebanyak 31 orang $(55,4 \%)$. Hasil serupa ditemukan pada penelitian yang dilakukan di Surakarta, menemukan lamanya operasi yang dibutuhkan paling banyak yaitu $>2$ jam sebanyak 56 kasus $(96,5 \%){ }^{5}$ Prosedur operasi kraniotomi yang cukup lama akan menyebabkan terjadinya peningkatan cedera cerebri yang selanjutnya akan mengakibatkan penurunan cerebral blood flow (CBF) hingga 50\%. Kejadian tersebut dapat ditandai dengan peningkatan $\mathrm{PaCO} 2$, yang pada akhirnya akan menginduksi hipoksia ataupun hiperkapnea. ${ }^{5}$

\section{Gambaran Kejadian HAP dan VAP Berdasarkan Lama Rawatan}

Berdasarkan hasil penelitian ini, kejadian HAP paling banyak terjadi pada pasien yang mendapatkan lama rawatan $>5$ hari di rumah sakit, yaitu sebanyak 6 orang (75\%). Kejadian VAP yang terjadi juga ditemukan paling banyak pada kelompok pasien yang mendapatkan lama rawatan $>5$ hari, yaitu sebanyak 22 orang (45,8\%). Penelitian yang dilakukan di Jambi menemukan lama rawatan terbanyak pada kasus VAP yaitu selama 4 hari $(13,64 \%) .10$ Penelitian di RSCM mendapatkan lama rawatan terbanyak pada kasus HAP yaitu selama $\geq 5$ hari $(86,3 \%) .{ }^{12}$ Kejadian HAP dan VAP terbukti memperpanjang durasi lama rawatam hingga 4,7 hari. ${ }^{25}$

\section{Gambaran Kejadian VAP berdasarkan Lama Pemakaian Ventilator Mekanik}

Berdasarkan hasil penelitian ini, kejadian VAP paling banyak terjadi pada pasien yang menggunakan ventilator $<96$ jam, yaitu pada 32 orang $(66,7 \%)$. Hasil yang serupa didapatkan pada penelitian di RSCM, menemukan lama pemakaian ventilator mekanik paling banyak yaitu $<5$ hari (52,2\%). ${ }^{11}$ Ventilator mekanik digunakan untuk menginduksi hipokapnea sehingga $\mathrm{PaCO} 2$ berada dalam kisaran normal. ${ }^{4}$ Kejadian VAP terbagi atas dua berdasarkan lamanya pemakaian ventilator mekanik, yaitu onset dini yang terjadi $<96$ jam dan onset lambat yang terjadi $\geq 96$ jam. ${ }^{9,13}$ 


\section{Distribusi Kejadian Pneumonia berdasarkan Patogen Penyebab}

Pada penelitian ini didapatkan patogen yang paling banyak menyebabkan kejadian pneumonia yaitu Acinetobacter baumnanii pada 17 orang (30,3\%) diikuti Klebsiella pneumoniae pada 14 orang (25\%). Pada penelitian yang dilakukan di RSCM juga mendapatkan organisme yang paling banyak ditemukan berupa Acinetobacter sp. (38,7\%) diikuti Klebsiella pneumoniae (25\%). ${ }^{11}$ Kejadian HAP dan VAP sebagian besar berawal dari aspirasi organisme orofaring menuju bronkus distal yang pada akhirnya terjadi proliferasi dan invasi bakteri pada parenkim paru. Pada keadaan normal, organisme di orofaring didominasi oleh Streptococcus viridans, dan organisme anaerob. Namun, pada kasus seperti pada penelitian ini, di mana pasien mangalami penurunan kesadaran dan penurunan pada refleks batuk yang menyebabkan penimbunan sekret, sehingga organisme yang dominan menjadi bakteri gram negatif aerobik dan Staphylococcus aureus. ${ }^{30}$

\section{Angka Kematian Kejadian Pneumonia pada Pasien Pasca Kraniotomi}

Pada penelitian ini ditemukan angka kematian kejadian pneumonia pada pasien pasca kraniotomi sebanyak 4 orang $(7,1 \%)$. Hasil penelitian ini lebih rendah dibandingkan hasil penelitian yang dilakukan di ruang ICU RSUD Raden Mattaher Jambi, menemukan angka kematian sebesar $59,09 \%{ }^{10}$ dan penelitian di RSCM juga mendapatkan angka kematian yang cukup tinggi yaitu sebesar 57,2\%. ${ }^{11}$ Angka kematian yang terjadi dapat dipengaruhi oleh beberapa faktor penyerta seperti usia, penyakit penyerta, dan jenis patogen yang menginfeksi.

\section{SIMPULAN}

Angka kejadian pneumonia pada pasien pasca operasi kraniotomi yaitu sebesar $26 \%$ dengan kejadian HAP sebesar 3,7\% dan VAP sebesar 22,7\%. Kejadian HAP lebih banyak terjadi pada perempuan $(62,5 \%)$ dengan kelompok usia 56-65 tahun (50\%) dan lama rawatan $>5$ hari (75\%), sedangkan VAP memiliki distribusi yang sama antara laki-laki dan perempuan $(50 \%)$ dengan kelompok usia terbanyak 36-45 tahun $(29,2 \%)$ dan lama rawatan $>5$ hari $(45,8 \%)$ serta lama pemakaian ventilator mekanik $<96$ jam (66,7\%). Komorbid yang paling sering terjadi pada penelitian ini berupa hipertensi $(21,4 \%)$ dengan diagnosis pra operasi yaitu meningioma (28,6\%), jumlah leukosit > $11.000(76,8 \%)$, dan lama pembedahan $>2$ jam $(55,4 \%)$. Hasil penelitian menunjukkan distribusi yang sama antara sifat pembedahan cito dan elektif (50\%). Kejadian pneumonia paling banyak disebabkan oleh mikroorganisme Acinetobacter baumanii (30,3\%) diikuti Klebsiella pneumoniae (25\%). Angka kematian yang didapatkan pada penelitian ini yaitu sebesar $7,1 \%$.

\section{DAFTAR PUSTAKA}

1. Garret MP, Spetzler RF. Craniotomy. In: Encyclopedia of Neurosurgical Science. USA: Elsevier, 2014: p.896-7.

2. Greenberg MS. Handbook of Neurosurgery 8th edition. New York: Thieme, 2016: p.1428-70.

3. Kaye AH. Essential Neurosurgery 3rd edition. Australia: Blackwell, 2005: p.40-183.

4. Tanriono C, Lalenoh DC, Laihad ML. Profil pasien pasca kraniotomi di ICU RSUP Prof Dr. R.D. Kandou Manado Periode Juli 2016-Juni 2017. Journal E Clinic Unsrat. 2017; 5(2): p.274-8.

5. Nurhadi MS. Profil Penggunaan Ventilator pada Pasien Post Operasi Kraniotomi E.C. Tumor Cerebri di Rumah Sakit Dr Moewardi Surakarta Tahun 2008-2010 [tesis]. Surakarta: Universitas Negeri Surakarta; 2014.

6. Souter MJ, Manno EM. Ventilatory management and extubation criteria of the neurological/neurosurgical patient. J Neurohospitalist. 2013; 3(1): p.29-45. 
7. Lalenoh DC, Lalenoh HJ, Rehata NM. Anastesia untuk kraniotomi tumor supratentorial. JNI. 2012; 1(1): p.16-24.

8. Dahlan Z. Pneumonia. Dalam: Buku ajar ilmu penyakit dalam. Edisi VI. Jakarta: Interna Publishing; 2014. p. 1608-18.

9. Nency C, Irawan D, Andrini F. Gambaran Kejadian Ventilator-Associated Pneumonia pada Pasien yang Dirawat di ICU dan CVCU RSUD Arifin Achmad Periode Januari 2013 s/d Agustus 2014. JOM FK. 2015; 2(2): p.1-9.

10. Sotianingsih, Samsirun H, Syauqi A. Gambaran klinis dan laboratorium pada pasien pneumonia di ICU RSDU Raden Mattaher Jambi. JMJ. 2019; 7(2): p.238-44.

11. Saragih RJ, Amin Z, Sedono R, Pitoyo CW, Rumende CM. Prediktor mortalitas pasien dengan ventilator-associated pneumonia di RS Cipto Mangunkusumo. eJKI. 2014; 2(2): p.77-84.

12. Halim S, Amin Z. Profil klinis pasien hospital acquired pneumonia di ruang rawat penyakit dalam. Ebers Papyrus. 2014; 20(1): p.19-28.

13. Guleria R, Madan K. pulmonary complications in neurosurgical patients. Ind J Neurosurgery. 2012; 2(1): p.175-80.

14. Lee HS, Moon J, Shin HR, Ahn SJ, Kim TJ, Jun JS, et all. Pneumonia in hospitalized neurologic patients: trends in pathogen distribution an antibiotic susceptibility. Antimicrobacterial Resistance and Infections Control. 2019; p.8: 25-33.

15. Savadekar A, Gyurmey T, Agarwal R, Podder S, Mohindra S, Gupta SK, et all. Incidence, risk factors, and outcome of postoperative pneumonia after microsurgical clipping of ruptured intracranial aneurysms. Surgical Neurology International. 2013; p.4:24.

16. Chu H, Dang BW. Risk factors of postoperative pulmonary complications following elective craniotomy for patients with tumors of the brainstem or adjacent to the brainstem. J Oncology letters. 2014; 8: p.1477-81.

17. Keilty S. Management of respiratory failure. In: Harden B, Cross J, Thomas S, editors. Respiratory Physiotherapy 2nd edition. USA: Elsevier; 2009. p.111-21.

18. Kesinger MR, Kumar RG, Wagner AK, Puyana JC, Peitzman AP, Billiar TR, et all. Hospital acquired pneumonia is an independent predictor of poor global outcome in severe traumatic brain injury up to five years after discharge. J Trauma Acute Care Surg. 2015; 78(2): p.396-402.

19. Kourbeti IS, Vakis AF, Ziakas P, Karabetsos D, Potolidis E, Christou S, Samonis G. Infections in patients undergoing craniotomy: risk factors associated with post-craniotomy meningitis. JNS. 2014; 122(5): p.1-7.

20. Bose G, Luoma AMV. Postoperative care of neurosurgical patients: general principles. J Anasthesia and intensive care medicine. 2017; p.1-8.

21. Sargin F, Sagiroglu AE, Dogru A, Gula M, Sayhan H, Tigen E. Etiology, incidence, and risk factors of ventilator associated pneumonia in an intensive care unit of training and research hospital in Istanbul. J Goztepe Tip Dergisi. 2013; 27(3): p.94-8.

22. Shretsa DK, Rajbhandari B, Pradhanang A, Sedain G, Shilpakar SK, Pradhan S. Ventilatorassociated pneumonia in neurosurgical patients: a tertiary care center study. JIOM Nepal. 2019; 41(2): p.40-4.

23. Liu Y, Di Y, Fu S. Risk factors for ventilatorassociated pneumonia among patients undergoing major oncological surgery for head and neck cancer. J Front Med. 2017; 11: p.23946.

24. Wu D, Wu C, Zhang S, Zhong Y. Risk factors of ventilator-associated pneumonia in critically ill patients. J Frontiers in Pharmacology. 2019; 10(482): p.1-7.

25. Zhang D, Zhuo H, Yang G, Huang H, Li C, Wang $\mathrm{X}$, et all. Postoperative pneumonia after craniotomy: incidence, risk factor, prediction with nomogram. Journal of Hospital Infection. 2020: p. 5-16.

26. Racca F, Vianello A, Mongini T, Ruggeri $P$, Versaci A, Vita GL, et all. Practical approach to respiratory emergencies in neurological diseases. J Neurological Sciences. 2019; 41: p.497-508.

27. Lacomis D. Respiratory dysfunction. In: Samuels MA, Feske SK, editors. Office practice 
of neurology 2nd edition. Churcill Livingstone: Elsevier; 2003. p. 137-43.

28. Nugroho AA, Arifin J, Hendriarto $H$. Pemeriksaan kultur sekret sebagai penunjang diagnosis untuk mengetahui kejadian ventilator associated pneumonia pada pasien pasca pembedahan di intensive care unit RSUP Dr. Kariadi Semarang. J Anastesiologi Indonesia. 2018; 10(2): p.93105.
29. Siqueira EMP, Diccini S. Postoperative complications in elective and non-elective neurosurgery. J Acta Paul Enferm. 2017; 30(1): p. 101-8.

30. Widyaningsih R, Buntaran L. Pola kuman penyebab Ventilator-associated pneumonia (VAP) dan sensitivitas terhadap antibiotik di RSAB Harapan Kita. Sari Pediatri; 13(6): p.38490. 